\title{
超音波パルスエコー法によるかまぼこ内部の 気泡の検査方法
}

\author{
高井陸雄*・鈴木 徹* ・三堀友雄* ・陳 正宜* \\ 発地由美子* . 小嶋秩夫*
}

\author{
Non-destructive Evaluation of Voids in Kamaboko by an \\ Ultrasonic Pulse Echo Technique
}

\author{
Rikuo TAKaI*, Tooru SuzuKI*, Tomoo MiHORI*, Seigi ChIN*, \\ Yumiko Hocchi* and Tuneo KozIMA* \\ *Tokyo University of Fisheries, Department of Food Science and Technology \\ 4-5-7, Konan, Minato-ku, Tokyo 108
}

\begin{abstract}
Kamaboko containing a lot of voids which arise from the air bubbles taken in the grinding process of fish meat during manufacturing is complained about its poor quality. An ultrasonic pulse echo technique was applied to evaluate the size and number of these voids in kamaboko by using a standard ultrasonic inspection apparatus (a single-type). The frequency used was $2.25 \mathrm{MHz}$. The number of voids larger than $1 \mathrm{~mm}$ diameter in kamaboko was determined by counting the number of ultrasonic echo pulses on the oscillograms. The number of echo pulses gradually increased as the increase of the number of voids while the voids' number was small. However, an abrupt saturation of detecting echo pulse took place. This may be caused by a rapid growth of the shaded space generated by void particles which reflected ultrasonic pulse wave. This phenomena was simulated by a simplified model calculation, which suggested a way of avoiding saturation. The non-destructive detection of voids in kamaboko using ultrasonic technique is concluded to feasible.
\end{abstract}

(Received May. 9, 1994)

かまぼこには，製造時に魚肉のらいかい過程で巻き込 んだ空気を核として多数の気泡が生成する．気泡径の大 きなもの，小さな径の気泡でも個数が著しく多いあのは 製品クレームの対象となる．熟練した技術者は製造ライ ンでかまばこをチェックしながら，大きな気泡を持つか まばこを，欠陥品として選別することも可能であるよう だが，このような技術を持つ人の数は限られており，こ の方法で品質の劣るかまぼこを取り除くことが出来る製 造ラインは極めて少ない，そこで，かまぼこ製造工程で 発生する気泡の有無, 多少を非破壊的に検查する方法と して超音波によるパルスエコー法の利用を検討した.

超音波探傷法の一種であるパルスエコー法は，金属の 溶接の際に内部に残留する微細な気孔の有無を迅速に検
查する方法として確立されたあのであり，取扱あ簡単で 習熟すれば確実に欠陥を探すことができる．しかしなが ら，食品の非破壊的な品質評価への適用例は数が未だ少 な(1)-4).

音波は物質が均一な場合，その内部を物質の固有の音 速で伝播するが，伝播の特性は音速（c）亡物質の密度 （○）との積である音響インピーダンス $(z=\rho c)$ によって 特徴づけられる，音波が音響インピーダンス $Z_{1}$ の物質 から $Z_{2}$ の物質に伝播するとき, 界面での音波の反射率 $\left(\alpha_{\mathrm{r}}\right)$ は $\alpha_{\mathrm{r}}=\left(Z_{1}-Z_{2}\right)^{2} /\left(Z_{1}+Z_{2}\right)^{2}$, であり, 透過率 $\left(\alpha_{1}\right)$ は $\alpha_{\mathrm{t}}=1-\alpha_{\mathrm{r}}$ である占）。加まぼこ主成分は水（60〜 75\%) であり, 内部の気泡は空気であると考えられる.

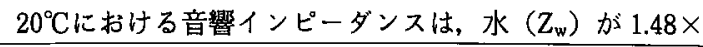

* 東京水産大学（干108 東京都港区港南 4-5-7） 
$10^{6} \mathrm{kgm}^{-2} \mathrm{~s}^{-1}$, 空気 $\left(Z_{\mathrm{a}}\right)$ が $4.00 \times 10^{2} \mathrm{kgm}^{-2} \mathrm{~s}^{-1}$ である から，水から空気へ音波が伝播する場合の反射率は $\alpha_{7}=$ 0.998 , 透過率は $\alpha_{\mathrm{t}}=0.002$ となり, 音波は, 水と空気の界 面でほぼ完全に反射する．したがって，かまぼこ内部に 気泡があると，音波は気泡の表面で強い反射を示し，こ の反射波（エコー）を観測することによりかまぼこ中の 気泡の存在を知ることができると考えられる.

本研究では汎用の金属用超音波探傷器を使用し，かま ぼこに含まれる気泡数の計数，あるいは大きな気泡の検 出を試みた。

\section{実 験 方 法}

\section{1. 試 料}

試料には，市販の 5 種類のリテーナ型かまぼこを用い た、比較のため, 冷涷すり身(FA 級)と食塩とを 100 対 3 の割合で混合した原料を真空らいかい機（STEPHANUM 5 UNIVERSAL) で 10 分間らいかいし，ケーシング （塩化ビニリデン製，折径 $47 \mathrm{~mm}$ ）に入れ，90ㄷ，40 分 間加熱してゲル化した「かまぼこ」す実験に供した.

\section{2. 実験装置}

測定には工業用超音波挆傷器 (三菱電気製, FD-410) を使用した。探触方法としては送信プローブと受信プ ローブとが兼用になっている1プローブ法を用いた. プ ローブ（探触子）には中心周波数 $2.25 \mathrm{MHz}$ をもつ, 直径 $15 \mathrm{~mm}$ の広帯域型（パナメトリック製，V 106）セラミッ クス振動子を使用した. プローブからパルス幅 $1 \mu \mathrm{s}$ の超 音波を照射し，その直後から反射波を受信した．受信信 号のオッシログラムは, 綻軸が音圧信号強度, 横軸は超 音波パルスの往復に要した時間を示す．湘定で得られる オッシログラム像を写真撮影し解析に供した。

\section{3. 実験手順}

（1）かまぼこ内部の気泡の測定

Fig. 1 に示すようにプローブを支持架台に固定し，か まぼこの上部からプローブを压着した．プローブとかま ぼこの間に空気層を作らないようにするため，かまぼこ の表面にグリセリンを叙布し，プローブと密着するよう にした.

（2）かまぼこ内部の状態の測定

プローブをかまぼこの山の頂上部に密着させ，長辺方 向へ $2 \mathrm{~cm}$ づつ順次ずらしながら，オッシログラムを写 真撮影した．その後, プローブをかまぼこの上部中央に 置いて，オッシログラムの写真撮影を行うと同時に，そ の位㯰におけるプローブ真下のかまぼこの切断面の気泡 の状態を記録した。すなわち，プローブ真下に超音波が
伝播する仮想的な円柱を考え，この円柱の中心軸に沿っ てかまばこを切断し，この仮想的な円柱の切断面にス夕 ンプインクを塗り，紙に押しつけその印影をとり，切断 面にある超音波の波長以上の直径 $(0.7 \mathrm{~mm}$ 以上) を有す る気泡の数 $(\mathrm{v})$ を数えた。

(3) かまぼこ中の音速の測定

かまぼこ中を伝播する超音波の波長と音響インピーダ ンスとを決めるためにかま代こ中の音速を測定した。加 まばこから，一様な厚さ， $2.0 \mathrm{~cm}$ 試料を切り出し，プ ローブ面に密着させ, 超音波が試料の㕌み方向に伝播 し，戻ってくるまでの時間（t）をオッシログラム上で決 定した。試料厚さの 2 倍の距離をこの時間で除してかま ぼこ中の音速とした

\section{実験結果及び考察}

\section{1. かまほこ中の音速}

本実験に使用した 4 種類のかまぼこ中の音速と水分含

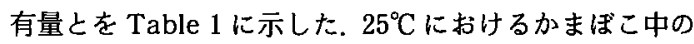
音速は (1.49-1.59) $\times 10^{3} \mathrm{~m} \cdot \mathrm{s}^{-1}$ であり水の音速（1.50X $\left.10^{3} \mathrm{~m} \cdot \mathrm{s}^{-1}\right)$ にほぼ等しい值であった．水を含むゲル状 食品の音速は水のそれにほぼ等しいと言われている8

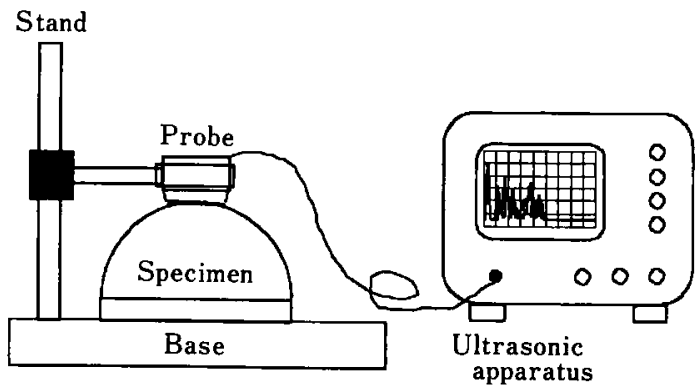

Fig. 1 Schematic diagram of experimental apparatus

Table 1 Sound velocity and the water content of kamaboko

\begin{tabular}{ccc}
\hline Kamaboko & $\begin{array}{c}\text { Sound speed at } 25^{\circ} \mathrm{C} \\
\text { m/sec }\end{array}$ & $\begin{array}{c}\text { Water content } \\
(\%) \text { (wet base) }\end{array}$ \\
\hline A & 1590 & 69 \\
B & 1490 & 73 \\
C & 1510 & 71 \\
D & 1492 & 71 \\
E & $-*$ & 78 \\
\hline
\end{tabular}

* no measurable with many air voids 
が, 水分が 70\%程度のかまぼこでも水と同じ音速をもつ ことがわかった，したがって，かまぼこ内部を伝播する $2.25 \mathrm{MHz}$ の超音波の波長はおおよそ $0.67 \mathrm{~mm}$ 程度であ ると推定できた。

かまばこの密度は (1.03-1.05) $\mathrm{kg} \cdot \mathrm{m}^{-3}$ であり，水と ほぼ等しいので，かまぼこの音響インピーダンスは水と ほとんど一致することがわかった。

\section{2. かまほこ内部の気泡の検査}

かまぼこ内部からのエコーはおおむね Fig. 2 に示す ような 3 種類の形に分けることができた。

(1) 気泡の極めて少ないかまぼこの測定例

真空らいかいしたかまぼこ原料をケーシングに詰めて 作ったかまぼこから切り出した厚さ $2 \mathrm{~cm}$ の試料につい て求めたオッシログラムをFig. 2 A に示した. 左端のパ ルスは照射波に対応するあので，他の3つのパルスはか まぼこの底面から反射してきたエコーのパルスだと認め られる.これらのパルスの外には気泡から反射してきた と考えられるパルスはほとんど見えない。これはかまぼ こ内部に気泡が極めて少ないためと考えられる。

(2) 市販のかまぼこの測定例

Fig. 2B，2C は市販のかまぼこの測定例である．いゔ れのオッシログラムにおいても，左端は照射波パルスで ある.Fig. 2Bでは底面からのエコー（矢印个）が明瞭に 認められるが，Fig. 2C では底面からのエコーが認めら れない．Fig. 2 B には照射パルスと底面からのパルスの

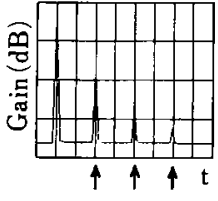

A

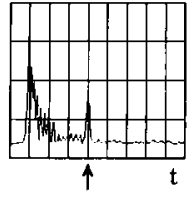

B

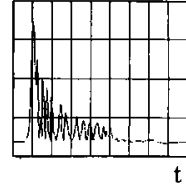

C
Fig. 2 Sample oscillograms of ultrasonic pulse echoes from kamaboko with wooden plate

A : Kamaboko was prepared in the vacuumed vessel and it had no voids. Arrows mean the pulse echoes from the bottom of kamaboko.

B : Kamaboko was made by the standard process and had a lot of voids. The pulse echo from the bottom appeared. Kamaboko had a lot of voids and the

$C$ : pulse echo from the bottom mixed up pulses from the voids.
間にいくつかの小さなパルスを見ることができるが，こ れらは内部に存在していた気泡からのパルスェコーと思 われる．他方，Fig. 2Cでは多数のパルスが観察できた。 これらはかまぼこ内部に気泡が多数あったためと思われ る.この場合, 多数の気泡のため超音波が散乱・減衰し， 底面からのエコーが観測できなかったすのと思われる。

(3) かまぼこ内部の気泡数の推定

超音波のオッシログラム上で，照射波と低面エコーと の間に観察できるパルスは，照射波がかまぼこ内部の気 泡で反射して戻ってきた信号と考えられる。プローブに 到達する時間が近接している複数のパルスはそれぞれを 独立したパルスとして認めることは困難であろうが，そ の合成されたパルスの信号強度を増加する效果を果たす であろう。したがって，気泡からの反射に由来するエ コーパルスの波形を解析すれば気泡に関する情報が得ら れるものと考えられるが，その解析は複雑なあのになる であろう．本研究では取扱を簡単にするため，オッシロ グラム上で識別可能な独立したパルスの数 $(\mathrm{P})$ を数え， それがかまぼこ内部の気泡数によ゙のように対応するかを 検討した。

Fig. 3 はこのようにして数えたパルスの数（P）をプ ローブ面から底面までの距離（h）とプローブの直径の 積で除した值を横軸に，プローブ真下の仮想的円柱の切

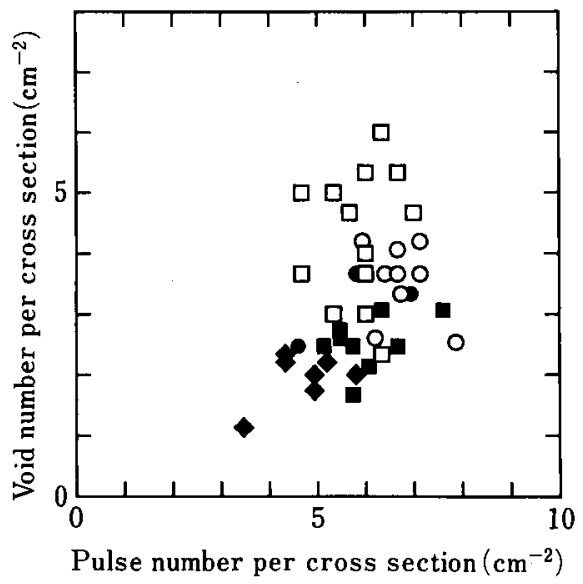

Fig. 3 Relationship between the number of pulse echoes on an oscillogram and the number of voids in the cross section of the kamaboko beneath the probe

Every symbol means the same brand from the different companies. 
断面のスタンプインクによる印影から数えた気泡数 (v) を切断面積（S）で除した值を縦軸にプロットしたすの である，同図は一見して本湘定がばらつきの大きいあの であることを示している.これは，試料内の気泡の配置 がランダムであることに起因すると思われる．したがっ て，バラッキの改善には測定回数を増し平均化した值を 用いることが望ましい，また，Fig. 3 はかまぼこ中の気 泡数が増加するとパルス数が飽和してしまう傾向を示し ている.

（4）かまぼこ板の上に生成する大きな気泡

かまばこと板との面には大きな気泡が発達し空洞状態 にまで至ることがある、この様に大きくなった気泡は前 節で扱った小気泡に比べ，存在を確認することは比較的 たやすかった，プローブを同一試料のかまぼこの頂上部 で，左から右へ移動してパルスエコーを採取した例を Fig. 4 に示した. Fig. 4 A には底面加らのエコー（个）が 見られるが，Fig. 4 Bにはこの底面位置に対応するエ コーは見られず，それよりも短時間で戻って来る強いエ コー（†）のパルスをとらえることができた。これはか まぼこ板の面よりあ浅い位置になんらかの広い境界面が 有ることを示唆した。ささらにプローブを左に移動させた

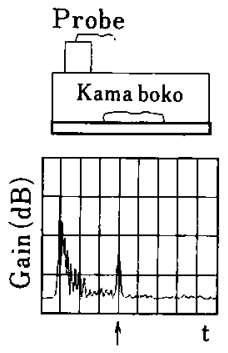

A
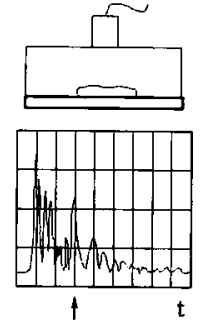

B
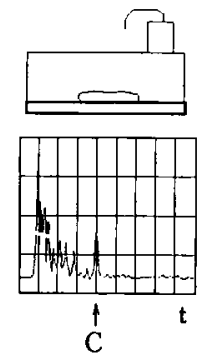

Fig. 4 Schematic diagram for detecting a large size void at the bottom of kamaboko

A : The probe was put on the left top of kamaboko. The pulse echo from the bottom of the kamaboko appeared clearly $(\uparrow)$.

B : The probe was placed above a huge void. The pulse echo from the bottom disappeared and another one from the huge void appeared at an early point on the time axis.

C : The probe was put on the right top of kamaboko. The pulse echo from the bottom appeared in the oscillogram.
ところ，再び底面からのエコー（个）を確認することが できた（Fig. 4C)．この検查の後，かまぼこ板を取り去 り底面を観察したところ，底面付近には図に示すよう な，大きな気泡が確認できた。

3. 気泡数計測のシミュレーション

本節ではかまぼこ内部の気泡数を推定した本実験の結 果 (Fig. 3) を，簡単な数学モデルによってシミュレー ションし, 更に, その結果に基づいて超音波パルスエ コー法によるかまぼこ内部の気泡数の推定に有利な装置 条件について論ずる.

（1）切断面のスタンプ印影に現われる気泡数

体積 $\mathrm{W}$ の媒体の中に直径 $\mathrm{d}$ の球状の気泡が $\mathrm{N}$ 個均等 に分布する系を考える．この媒体を断面積 S の平面で切 断するとき，切断面に見いだされる気泡の数を $\mathrm{n}$ 個とす る. 側面積が S で体積が W の立方体を Fig. 5 の一点銷 線で示す平面で切断する. 切断面は側面に平行とすれ ば, 断面の面積はSである.この断面によって切断され る気泡は，断面から士d の距離の範囲に含まれているも のに限られる。気泡が切断される領域の媒体体積は $2 \mathrm{dS}$ である.したがって，切断される気泡数（n）は

$$
\mathrm{n}=2 \mathrm{dSN} / \mathrm{W}
$$

となる，更に，この関係は媒体がどのような形状になっ てむ変わらない，気泡の直径の 2 倍よりむ試料が十分厚 いものならば，体積が W の任意の形状の立体に対し， 切断面の面積が S であ机ばこの関係は適用できる。な お，切断面に色素を塗布してスタンプを作成し，その印 影から n を計数する場合は, 認識可能な最小の気泡の印 影の寸法 q（份解能の限界）が存在するであろう。その 場合は上式の右辺の d を修正し,

$$
n=\left\{d+\left(d^{2}-q^{2}\right)^{1 / 2}\right\} S N / W
$$

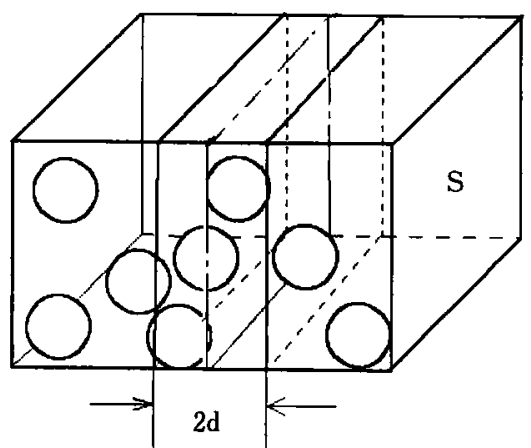

Fig. 5 Schematic void arrangement in a kamaboko model 
とすればよい。

切断される気泡数 $\mathrm{n}$ を切断面積 $\mathrm{S}$ で除すと, 試料中の 気泡の濃度 $(\mathrm{N} / \mathrm{W})$ を代表する值が得られる。

（2）超音波パルスの数

i ）超音波の進行方向にたいする気泡の識別能

媒体中に気泡が2つあると，そ扎らの深度 L（セン サーからの距離) に対応した時間軸上の位置 $(\mathrm{t}=2 \mathrm{~L} / \mathrm{c})$ にそれぞれのパルスが現われる．2つの気泡の深度が接 近していると，それらのパルスは重複し，あたかも $1 つ$ のパルスのように観測される，パルス幅 $\delta \mathrm{T}$ の送信パル スを用いて観測する場合，この装置によって識別可能な 分解能深度 $\varepsilon$ は $\delta \mathrm{T}=2 \varepsilon / \mathrm{c}$ によって決まる ${ }^{9)}$. この議論 は 3 個以上の気泡からのパルスの重複についても適用で きるだろう，Fig. 6 にその概念を示した，Fig. 6A の枠 は 7 個の気泡を含む媒体を示している.この左側面より 超音波を照射した時に得られるエコーは，Fig. 6Bの様 になると思われる，中央部の 3 個の気泡の深度の差は小 さいのでそれらのエコーパルスは重複し，あたかも1つ のパルスとして現われるであろう．同様に右端の 2 つの 気泡のエコーも1つのパルスとして観測される.した がって，7 個の気泡が存在するにあかかわらず，パルス は 4 個と観測される。

ii）超音波の陰に入った気泡の識別

超音波の進行方向に対し上流にある気泡は音波の進行 方向，すなわち，下流に対し，陰を作る.この陰に入っ た気泡からエコーは返らないのでパルスは数える事がで

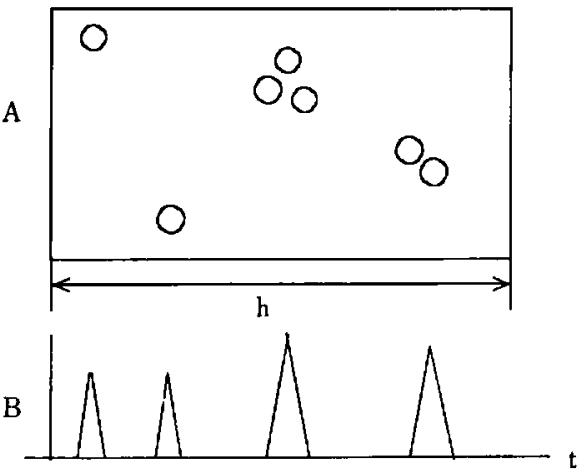

Fig. 6 Schematic model of the pulse echo from the isolated and the interacted voids each other

A : The position of voids in the kamaboko.

B : The pulse echoes from the voids.
きない.

(3) 気泡数計測のシミュレーション

以上の様に考えると，超音波パルスエコー法による気 泡の測定は，『プローブ面と試料の厚さとで囲まれる3 次元の領域内にランダムにN 個の気泡が分散している とき，超音波の進行方向に対し，気泡が作る超音波の陰 に入らず，しかも超音波の進行方向に対し気泡の中心間 の距離が $\varepsilon$ 以内に集合した気泡クラスターの数を求め る』問題に帰着する，そこで，この問題を簡単な数值実 験に因って検討した.

プローブの接触面は一辺10正方形とし，かまぼこ試 料の厚さを $\mathrm{h}$ とする. $\mathrm{N}$ 個の気泡をランダムに配置する ため，気泡位置の座標 $(\mathrm{X}, \mathrm{Y}, \mathrm{Z})$ について，X，Y 座 標に対し 0 から 1 までの，また，Z座標に対しては 0 か らhまでの一様乱数を発生させる，ただし， $Z$ 軸方向を かまぼこの厚さの方向とし，この方向に音波が伝播す る.まず， $\mathrm{N}$ 個のすべての気泡について Z 軸座標の大き い順に並び変える. 次に超音波の進行方向に対し，陰に 入る気泡を取り除く，そのために，順次気泡を XY 平面 に投影し，先に投影された気泡との距離が気泡の直径 $\mathrm{d}$ より向小さくなっている気泡を順次取り除く，この操作 で残った気泡のうち超音波の進行方向に対し識別可能な 距離だけ離れているのものを求める。 つまり，気泡のZ 朝座標の差が $\varepsilon$ 以内にある場合は 1 つのクラスターと見 なし，計数可能なパルスの数には加算せず，求めた差が $\varepsilon$ 以上の場合に計数可能なエコーパルスとして観測され るものとし，パルスの計数に 1 を加算する.

試料の単位体積中の気泡の数を 1 から $\mathrm{N}$ まで変化さ せこの様な計算を行った例を Fig. $7 \mathrm{~A}, 7 \mathrm{~B}$ に示した。

Fig. $7 \mathrm{~A}$ はプロープの一辺の長さを $1.5 \mathrm{~cm}$ とし, 試料の 厚さを変えた場合の，また，Fig. $7 \mathrm{~B}$ は試料の厚さを 2.0 $\mathrm{cm}$ とし，プローブの一辺の長さを変化させた場合の気 泡の数とパルス数との関係を示したあのである.同図上 り，計測されるパルス数は試料中の気泡数ととあに増加 するが，気泡数が一定数以上になるとクラスターが大き くなったり，上流の気泡の陰にはいる気泡の数が增える ために計測されるパルス数が飽和してしまったり，逆に 減少していくことがわかる.

Fig. 3 に示した本研究の実験は，プローブの一辺が $1.5 \mathrm{~cm}$ で試料厚さが $2 \mathrm{~cm}$ であったから, Fig. $7 \mathrm{~A} の \bigcirc$ に対応する．同図はFig. 3 のデータの挙動と良く一致し ており，気泡数の増加とともにパルスの数が飽和してゆ く状態を良く示している．本節で採用したモデルが，超 音波エコーパルス数の計数に因ってかまぼこ内部の気泡 


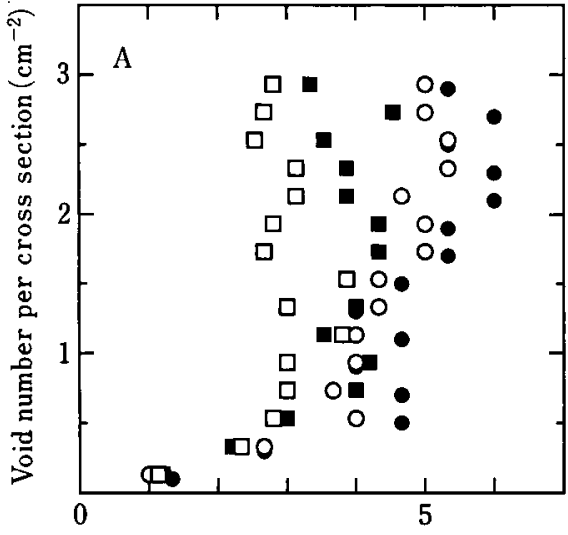

Pulse number per cross section $\left(\mathrm{cm}^{-2}\right)$

Fig. 7 Simulations of the relation between the number of echo pulse per unit cross section area of sample and that of voids in kamaboko

Fig. 7 A Transmitter/receiver probe size was $1.5 \mathrm{~cm} \times 1.5 \mathrm{~cm}$.

Sample thickness :

$0,1 \mathrm{~cm} ; 0.2 \mathrm{~cm} ; \square, 4 \mathrm{~cm} ; \square, 6 \mathrm{~cm}$.

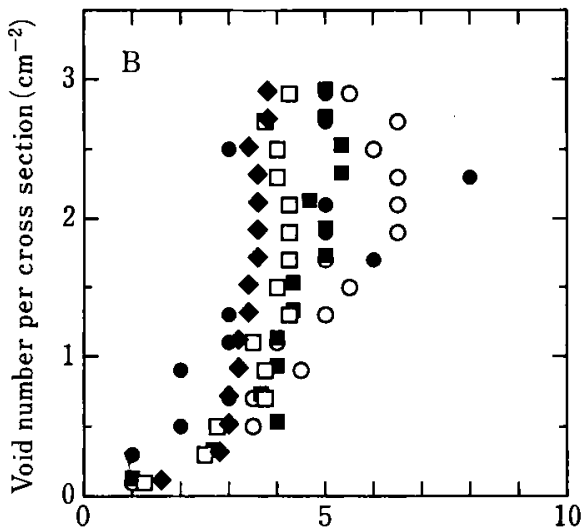

Pulse number per cross section $\left(\mathrm{cm}^{-2}\right)$

Fig. $7 \mathrm{~B}$ Sample thickness : $2 \mathrm{~cm}$. Transmitter/receiver size

- $0.5 \mathrm{~cm} \times 0.5 \mathrm{~cm} ; \bigcirc, 1.0 \mathrm{~cm} \times 1.0 \mathrm{~cm} ; \square, 1.5$ $\mathrm{cm} \times 1.5 \mathrm{~cm} ; \square, 2.0 \mathrm{~cm} \times 2 \mathrm{~cm} ; \bullet, 2.5 \mathrm{~cm} \times 2.5$ $\mathrm{cm}$.

数を推定しようとする本研究の実験結果を予湘する有用 な手段であることを示唆している。

(4) 測定条件の検讨

Fig. 3 の結果はばらつきが大きい上に飽和現象が現わ
れており, 気泡数の推定という目的には不利である.ば らつきを押さえ，飽和現象を避ける方法を Fig. 7 から検 討した。

Fig. $7 \mathrm{~A}$ から明らかなように，プローブの大きさが一 定の場合, 試料の厚さが厚いむのほど早くパルスが飽和 する事がわかる。これは試料が厚くなると重なり会う気 泡倠えてくることによるものと思われる，陚料の厚み を薄くすると，気泡が重なりあう確率は減るすのの，試 料全体を代表するという条件に乏しくなる．Fig.7Bよ り，プロープの断面積を大きくすると飽和が始まるパル ス数は大きくなるものの, 気泡の数が少ない部分のパル 又数に対する感度は悪くなる，したがって，本研究の方 法で沉用的な“気泡数検查装置”を作ることは困難であ るが，検查対象となる製品に含まれる気泡数密度に対応 した最適なプローブ寸法や測定長さを，本シミュレー ションによって決定し，単能な検查装置を作ることは可 能なものと考えられる。なお，バラッキが大きいことは， 測定を自動化し，多数回の測定の平均值を用いることに より克服できよう．市販のかまぼこに含まれる気泡の個 数がスタンプの個数で 1 6 個/ $\mathrm{cm}^{2}$ であることを考え 合わせると，本実験で採用した直径 $1.5 \mathrm{~cm}$ のプローブ でかまばこの山の高さに当たる，厚さ $2 \sim 3 \mathrm{~cm}$ の試料を 測定することにより内部に含まれる気泡の個数の状態を おおよそ把握できるものと思われる。

要 約

かまぼこ内部に存在している気泡の状態を沉用の金属 用の超音波探傷器を使用し，1プローブ法によって検查 する方法を㭘討した，試料には市販のかまぼこを 5 種類 使用した．以上の実験の結果，以下のことが明らかに なった。

（1）かまぼこの音響インピーダンスは水とほぼ等しい ため, かまぼこ内部の気泡の界面で音波はほぼ完全に反 射する.このため，かまぼこ内部に存在する気泡の有無， 大小を超音波パルスエコー法によって非破壊的に検查す ることが可能であった。

(2) 超音波オッシログラム上から読み取れるパルスの 個数とかまばこ内部に存在している気泡数との間には複 雑な関係があるものの，気泡数が少ない場合にはパルス の個数も少なく両者は比例関係を示した。しかし，気泡 数の増加之ともにパルス数は一定值に飽和し，気泡数の 計測は困難となった。このような関係は簡単なモデルに よる計算からも明らかになった。このような手法によっ て気泡の数を正確に求めることは困難ではあるあのの, 
プローブ径，試料の厚さを選択する事により気泡の多少 を非破壊的に検查可能であることがわかった.

本研究において真空らいかいを施したかまぼこの調製 を扣願いした，（株）マルハ中央研究所星昌和博士に謝意 を表します。

\section{文献}

1）吉武 充: 食品品質成分の非破壊分析測定法, 食 品研究刊行会, p.29 筑波 (1985).

2) Povey, M.J.W and Harden, C.A.:J. Food Technol., 16, 167 (1981).

3) Miles, C.A., Fursey, G.A.J. and Jones, R.C.D. : J. Sci. Food Agric., 36, 215 (1985).

4) Hafsteinsson, H., Parker, K., Chivers, R. and
Rizvi, S.S.H. : J. Food Sci., 54, 244 (1989).

5）実吉純一・菊池喜亮・能本乙彦：超音波技術便覧 (日刊工業新聞社，東京)，p.720（1987）。

6) ENSMINGER, D. : Ultrasonic, (Marcel Dekker, Inc., New York), p. 229 (1973).

7) Kinsler, L. and FreY, A.R. : Fundamentals of acoustics: (John Wiley \& Sons, Inc. New York), p. 128 (1950).

8) KRESS - ROGERS, E. : Instrumentation and Sensors for the Food Industry, ed by KREssROGER, E (Butterworth - Heineman Ltd., Oxford). p. 237 (1993).

9）日本超音波医学会編，超音波医学（第 2 版），(医 学書院, 東京) p. 108 (1980).

(平成 6 年 5 月 9 日受理) 